\title{
Editorial
}

\section{RACISMOS E MIGRAÇÕES}

Roberto Marinucci*

A derrocada de formas institucionalizadas de racismo - como o apartheid sul-africano ou a segregação racial nos EUA - acoplada à abolição da escravidão, ao amplo processo de descolonização no Sul do mundo e, sobretudo, à quase que generalizada condenação da Shoá, gerou a espraiada sensação de superação definitiva do espetro racial, teórico e prático. A permanência marginal de preconceitos com base racial era interpretada como um mero resquício de uma mentalidade destinada a sucumbir à lógica hegemônica e progressiva dos direitos humanos.

$\mathrm{Na}$ atualidade, no entanto, num contexto caracterizado por intensas mudanças socioculturais, que coincidiram inclusive com a crescente visibilidade do fenômeno migratório, ocorreu a erupção de novas e antigas formas de racismo. Houve uma metamorfose do racismo clássico (bioracial) em formas mais camufladas - como a racialização e essencialização de identidades étnicas, culturais, religiosas e nacionais - sendo que permaneceu análoga a lógica subjacente de inferiorização de minorias - por vezes, majoritárias - internas ou externas. Em outros termos, os novos racismos (neoracimos) se estruturam em modo polivalente, assumindo configurações diferenciadas em decorrência de variáveis contextuais.

É nesse contexto de recrudescimento de populismos, nacionalismos e sovranismos (Balibar, 1991) que se inserem as difundidas políticas migratórias restritivas e "malthusianas", que legitimam e são legitimadas pela nova onda do delírio racista, principalmente na versão da xenofobia. Essas políticas encarnam as duas formas tradicionais de racismo, que Taguieff (1999) denomina de "racismo de aniquilamento" e "racismo de exploração": a primeira visa à eliminação física de um determinado grupo social, enquanto a segunda sua exploração. As políticas imigratórias restritivas e securitárias, por um lado, provocam - de forma ativa ou omissiva - a morte de milhares de migrantes e solicitantes de refúgio, reduzindo - malthusianamente - o número de ingressos; por outro, alimentam dinâmicas de ilegalização e deportabilidade (De Genova, 2002) que possibilitam a inclusão subordinada e a consequente exploração dos recém-chegados. Em

Editor chefe da Revista REMHU, Centro Scalabriniano de Estudos Migratórios. Brasília, DF, Brasil. 
outros termos, são políticas que visam à criação de um limiar - físico e simbólico - além do qual a vida humana se torna menos humana, "vida sagrada" (Agamben, 2005), refugo humano (Bauman, 2005).

Neste cenário assombroso, no entanto, não podem ser olvidados os sinais de resistência, como o surgimento das assim chamadas "cidades refúgio" ou o compromisso de numerosas pessoas e ONGs que acolhem, partilham e acompanham - no sentido etimológico de "comer pão juntos" - migrantes e refugiados, inclusive desafiando formas institucionalizadas de racismo como no caso das legislações que criminalizam a solidariedade. Não pode ser menosprezada também a luta cotidiana de migrantes e refugiados em busca de estratégias de sobrevivência: suas presenças "abjetas" e suas ações reivindicativas contribuem a levantar a questão dos princípios éticos que deveriam pautar a convivência dos seres humanos.

Longe de advogar por uma visão maniqueísta da sociedade, o que preocupa é que na conjuntura atual se perdeu o medo ou a vergonha de manifestar atitudes e comportamentos de cunho racista, como comprovado pelo ressurgimento da Ku Klux Klan nos EUA ou a difusão de grupos neofascistas apoiados ou tolerados por relevantes representantes do mundo cultural e político. Isso representa um sério perigo para o futuro do gênero humano, pois negar ou reduzir a humanidade de alguém por motivos raciais, étnicos, religiosos, de gênero ou naturalidade, significa construir o que Stefano Rodotà (2015) chamava de "humanidade por subtração" (umanità per sottrazione), com todas as suas bárbaras consequências. A história docet.

O Dossiê do número 53 da REMHU, Revista Interdisciplinar da Mobilidade Humana é dedicado a esse tema. Os primeiros dois artículos, de Fabio Perocco e Enzo Pace, focam a questão da islamofobia, enquanto racialização dos muçulmanos - "the Muslim race" (p. 29). Perocco enfatiza os mecanismos de funcionamento dessa discriminação e, sobretudo, seus principais atores, enquanto Pace chama atenção sobre os nexos entre a questão religiosa na Europa e a difusão de populismos e nacionalismos: as religiões podem legitimar formas de racismo quando renunciam à pretensão de serem depositárias de valores universais e assumem posturas radicalmente sectárias e particularistas.

Os artigos de Antonia Olmos Alcaraz e Laura Escudero Zabala apresentam duas formas de manifestação do racismo, ambas marcadas por algum tipo de dissimulação. Olmos Alcaraz analisa narrativas do Facebook e sustenta que as redes sociais virtuais estão transmitindo um "virus con una alta capacidad infecciosa" (p. 57) - o racismo - fomentado tanto pelo possível "anonimato" - e, portanto, pelo reduzido controle social - quanto pela "rapidez" da ferramenta, que dificulta o aprofundamento do tema. Escudero Zabala, por sua vez, se debruça sobre o racismo sutil e camuflado das relações interpessoais do dia a dia e as reações emotivas e corporais que provoca nos sujeitos que o sofrem. 
Alexandre Branco Pereira apresenta reflexões etnográficas a partir do estudo de um serviço de assistência em saúde mental para refugiados. Entre as diferentes ponderações, chama atenção o tema racial que aparece tanto na tendência, geralmente involuntária, em estabelecer um nexo quase que automático entre cor da pele e refúgio, quanto na invisibilização da questão racial, pois "tratar as experiências díspares do refúgio branco e do refúgio negro pasteuriza vivências desiguais" (p. 96).

Finalmente, os racismos institucionalizados são o foco dos últimos dois artigos. Susana Martínez Martínez e Delia Dutra abordam a relação entre racismo e imigração no Brasil. As autoras questionam a assim chamada "democracia racial" brasileira e sustentam que a chegada de estrangeiros africanos e haitianos desmasca um racismo que, de fato, nunca desapareceu na sociedade: "el racismo hacia los inmigrantes africanos y haitianos se da por una asociación en el imaginario colectivo con los negros brasileños, vinculado a la historia de la esclavitud y de la construcción social específica del racismo brasileño" (p. 111). Já Olivia Gall analisa, numa perspectiva diacrônica, as leis e as políticas migratórias do México desde o começo do século XX aos dias de hoje, bem como suas consequências perversas no contexto contemporâneo, sobretudo em relação às populações em trânsito e aos retornados/deportados dos EUA.

A seção Artigos é aberta por lana dos Santos Vasconcelos que se debruça sobre a situação dos Venezuelanos em Boa Vista, no Brasil. A autora aborda a temática na perspectiva da alimentação, evidenciando como os venezuelanos no ato de receber, enviar e compartilhar comida experimentam diferentes formas de interação social e desenvolvem a própria subjetividade, num complexo processo de negociação que envolve autonomia e sujeição.

Francesco Vietti reflete sobre a experiência de "accoglienza diffusa" na Igreja Católica na Itália, junto a refugiados e solicitantes de refúgio. Focando a reflexão a partir da perspectiva dos voluntários, o autor sublinha os aspectos positivos da experiência, mas também os riscos da assim chamada "razão humanitária" que, por vezes, pode desencadear relações paternalistas e assimétricas.

Os artigos de Angélica Alvites Baiadera e María Dolores Linares abordam, em termos gerais, as políticas migratórias na Argentina. Alvites Baiadera destaca as políticas de controle de fronteira na percepção de migrantes bolivianos e, após estabelecer um conjunto de "hitos de control", realça as estratégias subjetivas de enfrentamento desencadeadas pelos migrantes. Por sua vez, Linares aborda as mudanças ocorridas no funcionamento da Dirección Nacional de Migraciones na Argentina a partir da Ley $N^{\circ}$ 25.871. A autora foca a investigação "desde adentro", buscando averiguar se ocorreu, de fato, um "cambio de cultura organizacional" (p. 193), uma mudança de mentalidade por 
parte dos funcionários, sobretudo em se levando em conta a discricionariedade que caracteriza alguns aspectos do funcionamento da instituição.

María del Rosario Guerra González e Maribel Sánchez Matías se debruçam sobre o conceito kantiano de hospitalidade e apresentam argumentos jurídicos, filosóficos e morais para fundamentar políticas de acolhida de refugiados, que devem, no entanto, ser sempre contextualizadas.

Finalmente, André Zuzarte e Carolina Moulin aprofundam o tema dos refugiados urbanos a partir de duas perspectivas antitéticas: a cidade enquanto espaço de controle, disciplinarização e policiamento e a cidade enquanto lugar de politização, subjetivização e subversão. Nesta dialética entre práticas estatais de controle e estratégias de contestação, a cidade se apresenta como "território de experimentação democrática" (p. 227).

Na Seção Relatos e Reflexões, Ir. Marivane Chiesa apresenta o trabalho desenvolvido no Centro de Acolhida Bienvenu, em Joanesburgo, na África do Sul, junto a mulheres e crianças refugiadas, elucidando o perfil das pessoas acolhidas, as ações desenvolvidas e os principais resultados obtidos. A apresentação da tese de Dalila Raccagni encerra o número da Revista.

Desejamos a todas e todos uma boa leitura.

\section{Referências bibliográficas}

AGAMBEN, Giorgio. Homo sacer. II potere sovrano e la vita nuda. Torino: Einaudi, 2005.

BALIBAR, Etienne. Racismo y nacionalismo. In: WALLERSTEIN, Immanuel; BALIBAR, Etienne. Raza, Nación y Clase. Madrid: IEPALA, 1991.

BAUMAN, Zygmunt. Vidas desperdiçadas. Rio de Janeiro: Jorge Zahar Editor, 2005. DE GENOVA, Nicholas. Migrant "Illegality" And Deportability In Everyday Life. Annu. Rev. Anthropol., n. 31, p. 419-47, 2002.

RODOTÀ, Stefano. Di che cosa parliamo quando parliamo di umanità. La Repubblica, 07.12.2015.

TAGUIEFF, Pierre-André. II razzismo. Pregiudizi, teorie, comportamenti. Milano: Raffaello Cortina, 1999. 